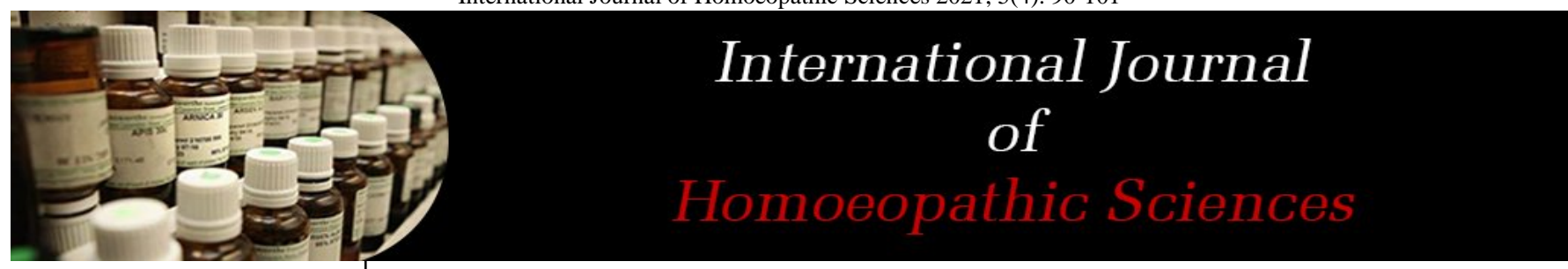

E-ISSN: $2616-4493$ P-ISSN: 2616-4485 www.homoeopathicjournal.com IJHS 2021; 5(4): 90-101 Received: 03-08-2021 Accepted: 04-09-2021

Dr. Sudhansu Sekhar Moharana

Professor, Department of Repertory, Yenepoya Homoeopathic Medical College \& Hospital, Naringana, Mangalore, Karnataka, India
Corresponding Author: Dr. Sudhansu Sekhar Moharana

Professor, Department of Repertory, Yenepoya Homoeopathic Medical College \& Hospital, Naringana, Mangalore, Karnataka, India

\section{The applied aspect of socio-psychic causation \& trait effect in the context of Swedenberg - Kentian concept of disease development with clinical prospective.}

\author{
Dr. Sudhansu Sekhar Moharana
}

DOI: https://doi.org/10.33545/26164485.2021.v5.i4b.456

\begin{abstract}
In modern era psychosomatic diseases are very common due to the race of competitive spirit, unsatisfied wants, and covetousness which creates various psychological personalities know as traits i.e. suspiciousness, Conscientious, dictatorial etc. It was the Swedenborg who first developed the concept of being mentally happy, physically healthy and socially benevolent to be mentally and physically healthy and realising the divine aura. Divine aura when descends it first purify soul, the influence of it is then realised in mind and lastly in body. This influx was realised by Dr. Kent. Dr. Kent after being homoeopath, discovered the origin of Hahnemann psora from 'Mental tension' and named it 'Internal itch' by the base of Swedenborg's influx principle. Dr. Kent theorised that man is healthy till he is good to his neibour, when he became jealous to others and think ill, the psora enters in the form of "Internal itch", first pollutes the spirit like vital force which first affects mind and then body. Man shows a deviated pattern of hypersensitiveness or dullness behaviour and physically intolerance to trivial environmental changes or foods. Kent advised to take care of those perverted Mental Generals and Physical generals which are the foundation of disease development. So Dr. Kent advised us to treat Man in disease, not the diseases of man. While investigating disease personality and healthy personality from patient, the Raymond B. Cattell's personality trait found to be unique fitting best to homoeopathic symptoms and rubrics. 16 personality factors of source trait and abnormal traits are defined with their equivalent rubrics for practitioners. Some obstinate cases are treated with sociopsychic causes rubrics (Internal itch of Kent) gave very remarkable curative results and some cases treated with trait rubrics yield also remarkable curative outcome. Thus it is the study of Swedenborg Kentian concept for prevention and cure of diseases and the study of Raymond B. Cattell's source traits and abnormal traits for enlighting Swedenborg - Kentian concept to treat the man in disease, not the diseases of man.
\end{abstract}

Keywords: Swedenborg-Kentian concept, source traits, R.B. Cattell's 16 personality factors, abnormal traits, rubrics, psora, mental itch, Influx.

\section{Introduction}

In modern scientific view, a mental tension is the mother of hundreds of psychosomatic diseases ${ }^{[1]}$. The same view was incorporated by Dr. Kent with analogy of Swedenborg philosophy that "Internal itch is the cause of psoric manifestation" [2]. Then psora gives rise to sycotic miasmatic and / or syphilitic miasmatic states - the mother all chronic diseases ${ }^{[3]}$. When we analyse the Swedenborg philosophy we find that "Divine love and wisdom emanate from the Lord, as a single whole” ${ }^{[4]}$. Further Swedenborg say about descendacy of Lord's grace is that "Man receives influxes of diverse qualities, good or evil, through the heavens or the hells" [5]. "Spiritual Influx," called by some 'Occasional Causes,' is praised because the soul, as a spiritual substance, is prior to the material body, and should consequently inflow into the latter" ${ }^{[6]}$. The common pattern of influx ${ }^{[7]}$ are seen in many places. Those are

- Spirit, mind and nature.

- Celestial, Spiritual and Spiritual-natural heavens - in spiritual.

- Loving, thinking, and acting - in mind (mental)

- $\quad$ Principles, causes and events - in natural physics.

Dr. Kent justified the Sweden bergian philosophy of healthy living by unfolding the truth ““'As long as man continued to think that which was true \& held that which was good to the neighbor that which was uprightedness \& Justice so long as man remains in the earth free from the susceptibility to the disease, because that was the state in which he was created" [8]. 
Thus influx of evil originated from man's jealousy what Kent described as "Internal itch" [9] first pollute soul like vital force, which reflects in mind, later reflects in body. This state of mental and physical change without an appreciable disease state, correspond to the Hahnemannian latent psora. At this state, any triggering factor can cause disease. This is because nosological classification of diseases and pathology are less important than mental and physical generals. Thus Dr. Kent's view was to 'treat the Man in Disease, Not the Diseases of Man' and the duty of the physician is to 'heal the sick'.

Then we have to understand what you know to describe about 'Man'. Dr. Kent in his Lecture state 'Mind is the Key to Man' [10]. 'Man consists what he thinks and what he loves' [11]. Thus "It points out the importance of the distinction between temperament and personality for studies in human and animal differential psychophysiology, psychiatry and psycho-pharmacology, sport and animal practices during the past century" [12].

G.W. Allport states personality is the unique dynamic organization within the individual of those psychophysical systems that determine the unique adjustment to his environment ${ }^{[13]}$. Thus two identical twins even differ in their behavior with certain unique characteristics in relation to response pattern to both physical as well as psychosocial environment. The sum of these mental and physical differential characteristics from others by external and internal environments are used in psychology for behavioral therapy and for development of interpersonal relationship whereas in homoeopathy the process is known as Individualization used for selection of remedy as well as for counseling as described Dr. Robert in his book 'The Principles and Art of Cure by Homoeopathy' in the chapter 'Analysis of case' ${ }^{[14]}$. Thus individual personality is stated as trait by Gulliford where "a trait is any distinguishable, relatively enduring way in which one individual differs from another" ${ }^{[15]}$.

Determination of Traits: A trait is determined by unique response to a specific stimuli. For example of Chauhan ${ }^{[16]}$ :

\begin{tabular}{|c|c|c|c|}
\hline & Stimuli & Trait & Responses \\
\hline $\begin{array}{l}1 . \\
2 . \\
3 . .\end{array}$ & $\begin{array}{c}\text { Meeting friends } \\
\text { Meeting with stangers } \\
\text { Dealing with poor and } \\
\text { disabled children }\end{array}$ & Friendliness & $\begin{array}{l}\text { 1. Helpful } \\
\text { 2. Pleasant } \\
\text { 3. Warm and } \\
\text { interested. }\end{array}$ \\
\hline
\end{tabular}

“According to R.B. Cattell, "traits are relatively permanent and broad reaction tendencies and serve as the building blocks of personality. He distinguishes between constitutional and environmental mold traits; ability, temperament, and dynamic traits; and surface and source traits." [17].

Unique traits ${ }^{[18]}$ : Unique traits are those precise to one person. It may be something extraordinary or peculiar or identifying to that person. For example, Abdul Kalam is the only person who could have able to develop missile technology in India without Cryogenic machine. Mohandas Karamchand Gandhi was the only person who had developed the humanity concept of put-forthing freedom of India in non-violent manner. Virtually all of cattell's work focuses on common traits, but his incorporation of the Unique - trait concept enables him to emphasize the fact that personalities are unique. This concept tallies with individualization concept in Homoeopathy.

Surface traits: "it is the collection of trait essentials, of greater or lesser width which is commonly found in many different individual's and circumstances" [19].

A source trait: It is the underlying factor that controls the variation in the surface trait." [20].

"According to Cattell, there is continuum of personality traits. In other words, each person contain all of these 16 personality traits to certain degree, but they might be high in some traits and low in others" [21]. Thus Cattell's personality source traits are elaborated with rubrics from Murphy's repertory.

The major Source traits in 16 Personality Factors of R. B. Cattell with rubrics from Murphy’s repertory ${ }^{[22]}$.

\begin{tabular}{|c|c|c|c|}
\hline Low Scored trait portrayal with link rubric(s) & Factor & Factor & High Score Scored trait portrayal with link rubric(s) \\
\hline Reserved (Schizothymia) Rubric: Mind, Reserve, mood & A- & $\mathrm{A}+$ & Outgoing (Affectiothymia) Rubric: Relaxed, mentally, Calmness \\
\hline Less Intelligent (low”8”) Rubric: Dullness, mental & B- & $\mathrm{B}+$ & More intelligent (high “8”) Rubric: Intellectual \\
\hline Emotional (low ego strength) Rubric: Emotions, strong & C- & $\mathrm{C}+$ & Stable (ego strength) Rubric: Calmness, Tranquility. \\
\hline Humble (submissiveness) Rubric: Submissive, Mild, and Passive. & E- & $\mathrm{E}+$ & Assertive (dominance) Rubric: Domineering disposition, Dictatorial. \\
\hline Sober (Desurgency) Rubric: Responsible, Over responsible & F- & $\mathrm{F}+$ & Happy - go - lucky Rubric: Carefree \\
\hline Expedient (low superego) Rubric: Careless, Heedless. & G- & $\mathrm{G}^{+}$ & Conscientious (high superego) Rubric: Conscientious, general \\
\hline Shy (Threctia) Rubric: Bashful, Timid & $\mathrm{H}-$ & $\mathrm{H}+$ & Venturesome (Parmia) Rubric: Courageous \\
\hline $\begin{array}{l}\text { Tough-minded (Harria) Rubric: Egotism, general. Haughty, } \\
\text { behavior. Boldness. }\end{array}$ & $\mathrm{I}-$ & $\mathrm{I}+$ & Tender-minded (Premsia) Rubric: Mildness disposition \\
\hline Trusting (Alaxia) Rubric: Indiscretion, Truth tells the plain. & L- & $\mathrm{L}^{+}$ & Suspicious (pretension) Rubric: Suspicious, mistrustful. \\
\hline Practical (Paraxernia) Rubric: Reason, increased power of & M- & $\mathrm{M+}$ & Imaginative (Autia) Rubric: Theorizing, general. Plans, general \\
\hline Forthright (artlessness) Rubric: Yielding, passive & $\mathrm{N}-$ & $\mathrm{N}+$ & Shrewd (shrewdness) Rubric: Perception, in general, increased. \\
\hline Placid (assurance) Rubric: Hopeful feeling & O- & $\mathrm{O}+$ & Apprehensive (guilt-proneness) Rubric: Hopeless feeling, Apprehensions. \\
\hline Conservative (conservatism) Rubric: Idea, general, fixed ideas & $\mathrm{Q}_{1^{-}}$ & $\mathrm{Q}_{1}+$ & Experimenting (radicalism) Idea, general, abundant \\
\hline Group tied (group adherence) Rubric: Company desire for & $\mathrm{Q}_{2^{-}}$ & $\mathrm{Q}_{2}+$ & Self-sufficiency(self-sufficiency) Responsible general, \\
\hline Casual (low integration) Rubric: Carefree & $\mathrm{Q}_{3^{-}}$ & $\mathrm{Q}_{3}+$ & Controlled (high self-concept) Rubric: Cautious behavior \\
\hline Relaxed (low ergic tension) Rubric: Playful & $\mathrm{Q}_{4^{-}}$ & $\mathrm{Q}_{4}+$ & Tense (Ergic tension) Anxiety, general \\
\hline
\end{tabular}

Abnormal Traits: Cattell has also derived 12 new factors that measures psychopathology. These are: 


\section{Major abnormal source traits of R. B. Cattell with link rubric(s)}

\begin{tabular}{|c|c|}
\hline Factors & Abnormal Source Traits portrayal with link rubric(s) \\
\hline $\mathrm{D}_{1}$ & High hypochondriasis: Shows over concern with bodily functions, health or disabilities. Rubric: Hypochondriasis, mental. \\
\hline $\mathrm{D}_{2}$ & Suicidal disgust: is disgusted with life, harbors thoughts or acts of self-destruction. Rubric: Suicidal disposition \\
\hline $\mathrm{D}_{3}$ & High brooding discontent: seeks excitement, is restless, takes risk, and tries new things. Restless, mental. \\
\hline $\mathrm{D}_{5}$ & Low energy euphoria: Has feeling of weariness, worries, lacks energy to cope. Rubric: Wearisome, burdened feeling. \\
\hline $\mathrm{D}_{6}$ & High guilt and resentment: Has feeling of guilty, blames self for everything that goes wrong, is critical of self. Rubric: Guilt, feeling. \\
\hline $\mathrm{D}_{7}$ & Iigh bored depression: Avoids contact and involvement with people, seeks isolation, shows discomfort with people. Rubric: Company, aversion to. \\
\hline $\mathrm{P}_{\mathrm{a}}$ & $\begin{array}{c}\text { High paranoia: Believes he or she is being persecuted, poisoned, controlled, spied on, mistreated. Rubric: Delusion, persecuted, that he is, Delusion, } \\
\text { poisoned, thought he had been, Delusion, abuse being. }\end{array}$ \\
\hline $\mathrm{P}_{\mathrm{p}}$ & $\begin{array}{c}\text { High psychopathic deviation: Has complacement attitude towards own or others’ antisocial behaviour, is not hurt by criticism, likes crowd. Rubric: } \\
\text { Anti-social behavior }\end{array}$ \\
\hline $\mathrm{S}_{\mathrm{c}}$ & $\begin{array}{c}\text { High Schizophrenia: Hear voices and sounds without apparent source outside self, retreats from reality, has uncontrolled and sudden impulses. } \\
\text { Rubrics: Hallucination sounds, listen to imaginary. Rubric: Mania, general }\end{array}$ \\
\hline $\mathrm{A}_{\mathrm{s}}$ & High Psychoasthenia: Suffers insistent, repetitive ideas, and impulses to perform certain acts. Rubric: Repeats the same action \\
\hline $\mathrm{P}_{\mathrm{s}}$ & $\begin{array}{c}\text { High general psychosis: Has feeling of inferiority and unworthiness, timid, loses control easily. Rubric: Timid. Rubric: Hopeless feeling, despair. } \\
\text { Rubric: Control, lack of emotional. }\end{array}$ \\
\hline
\end{tabular}

Utility of mental causation and abnormal or normal traits in treatment

Case No. 1: Ailments of Anxiety: A case of avascular necrosis of head of both the femur

Mr. A. aged 28 years, had allergic bronchial asthma with avascular necrosis of head of the femur of both the legs. He had severe mental agony with wife which resulted in divorce.

Present Complaints: He had pain in hip, limping \& was unable to sit in squatting position complained on $21^{\text {st }}$ August 2004. Severe pain in hip, which was aggravated by movements.

He was limping \& was unable to sit in squatting position. Both cough and hip pain is aggravated by cold. .All the problems were aggravated by alcohol to which he was used to especially after matrimonial anxiety. Patient had undergone allopathic treatment and core drilling by allopathic orthopedicians was already done.

The X-Ray: Patchy sclerotic / lytic areas are seen involving the right femoral head.

\section{Magnetic Resonance Imaging was done on $25^{\text {th }}$ July 2004.Findings}

- Hypointense crescent is seen within the right femoral head. Marrow within appears hypointense on both T1 and T2 weighted images. Some marginal irregularity is seen. Superior and anterior quadrants are involved.

- Articular cartilages are intact.

- Synovial effusion is seen.

- Hypointense crescent is seen within the left femoral head.

Grade II Avscular necrosis seen in right femoral head. Grade I Avscular necrosis seen in left femoral head.

\section{Conceptual image}

1. Causation: Severe anxiety due to matrimonial disharmony. 2. Causative modality: 3. Alcohol habit. 4. Motion aggravation. 5. Pathological general: Avascular necrosis. Inflammation of bones 6 . Severe bone pain. 7 . Asthmatic breathing.

Repertory used: Synthesis as causations are prevalent. Repertorial syndrome:
1. Ailment of Anxiety
2. Alcoholic drinks, aggravation
3. Motion aggravation
4. Extrimities,. Caries of Bones.
5. Inflammation bones
6. Pains bones.

P.D.F: Asthmatic breathing, aggravated by cold.

\section{Repertorial Result}

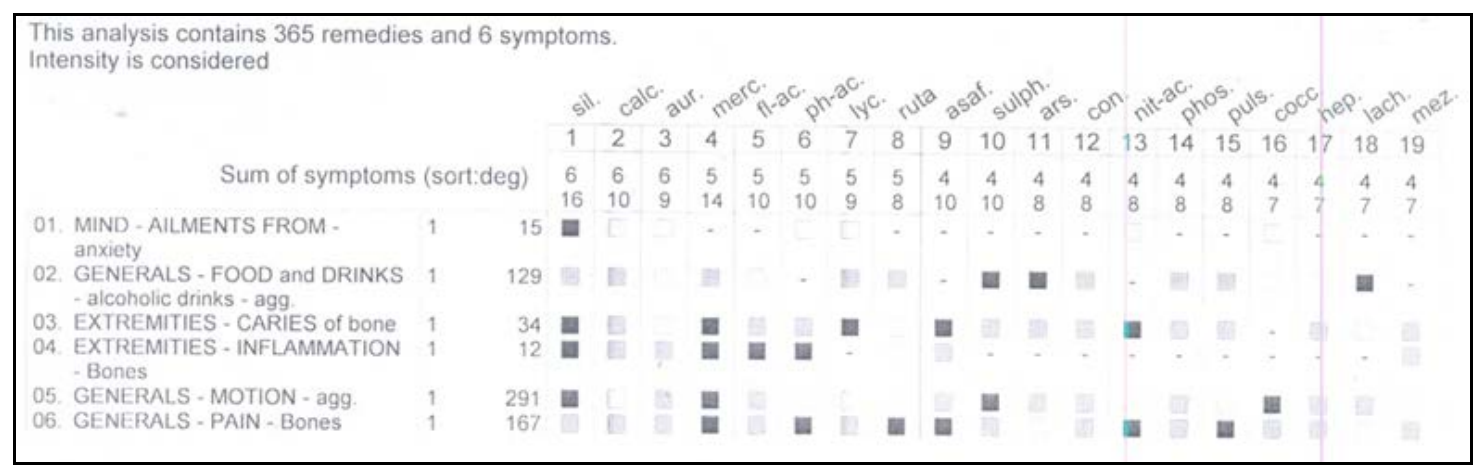

Post-Repertorial Result Analysis: Merc. 14/5 (Hot remedy as aggravated by heat - as per Allen's key note symptoms), Sulphur: 10/4. So Merc and Sulphur is eliminated as were hot remedy.
The high valued chilly remedies ware Sil.-16/6, Calc. 10/6, Ph-ac-10/5, Asaf-10/4 (both $3^{\text {rd }}$ grade heat and chilly remedy),.

Silicea may not be indicated here as silicea causes 
inflammation for removal of necrosed / dead tissues. So silicea is contraindicated where inflammation in vital parts not required although in this case scores highest value i.e., $16 / 6$.

\section{Defining calc carb for differentiation}

- It is chilly remedy.

- It is deep acting constitutional remedy.

- It has less action in controlling bronchial asthma due to anxiety.

- It cannot be repeated very often for acute condition of bronchial asthma and avascular necrosis due to anxiety.

\section{Defining Phosphoric acid for differentiation}

- It is also chilly and deep acting remedy.

- It can not also be repeated very often as acute remedy in water doses.

- Less value in controlling bronchial asthma due to anxiety.

Defining Asafoetida for selection of remedy more appropriate than Phosphoric acid \& Calcarea carb.

- Anxiety ailment of Asafoetida cannot be ignored as 3rd grade remedy as excess sensitivity due to anxiety can lead to somatisation to bone.

- Avascular necrosis leads to caries of bones, and for caries of bones, Asafoetida is the 1st grade remedy.

- Giving immidiate value to relief of pain Asafoetida is 1 st grade remedy.

- Asaf. Can be repeated in severe pain of avascular necrosis due to anxiety in water doses.

- In this case of psychosomatic bronchial asthma Asafoetida can be repeated in water doses.

$1^{\text {st }}$ Prescription: On $21^{\text {st }}$ August 2004, patient was given Asafoetida 30, 4 globules every 6 hourly in water doses. Justicea adhatoda Mother Tincture 15 drops every 6 hourly with water if patient gets bronchial asthma s.o.s. in spite of asafetida action.

After seven days on $28^{\text {th }}$ August 2004, patient reported that he is well of both bronchial asthma and severe pain in both limbs. He was discontinued to take Justicea adhatoda Mother tincture and kept in Asafetida 30, twice a day in water doses as patient's bronchial asthma may be precipitated in high potency.

After 15 days, on $14^{\text {th }}$ September 2004, patient reported that his pain is reduced but pain in deep pressure and was limping still. He begged permission to go to Dubai to attend the duty at his regular job. Asafoetida 30, twice daily was continued in water doses and permitted to join his job at Dubai. The patient was kept on Asfoetida 30, twice daily as we presume high potency may aggravate the acute episode and 50 mililisimal potency is not available to continue for a longer interval for pathological condition.

Patient continued Asafetida 30 twice daily in water doses in Dubai also. After one year patient was asymptomatic and when patient came from Dubai, he was observed that no pain and tenderness and limping. The MRI was done on $6^{\text {th }}$ day of September 2005 of both hip joints and the MRI finding report is as follows:

\section{Findings:}

- Hypointense crescent is seen within the right femoral head. Marrow within appears hypointense on both T1 and T2 weighted images. Minimal marginal irregularity is seen. Superior and anterior quadrants are involved.

- Articular cartilages are intact.

- No synovial effusion is seen.

- Hypointense crescent is seen within the left femoral head.

- Artocular margins are intact. Acetabuli appear normal.

- Post-operative changes are seen within both femoral heads. So, here we only find the Minimal marginal irregularity and diminution of synovial effusion only although pain is totally decreased. He is advised to continue Asafoetida 200, once daily in water doses for another two years as there was no asthmatic episode. Meanwhile he is again married and leading a happy wedded life.

\section{MRI report before treatment}

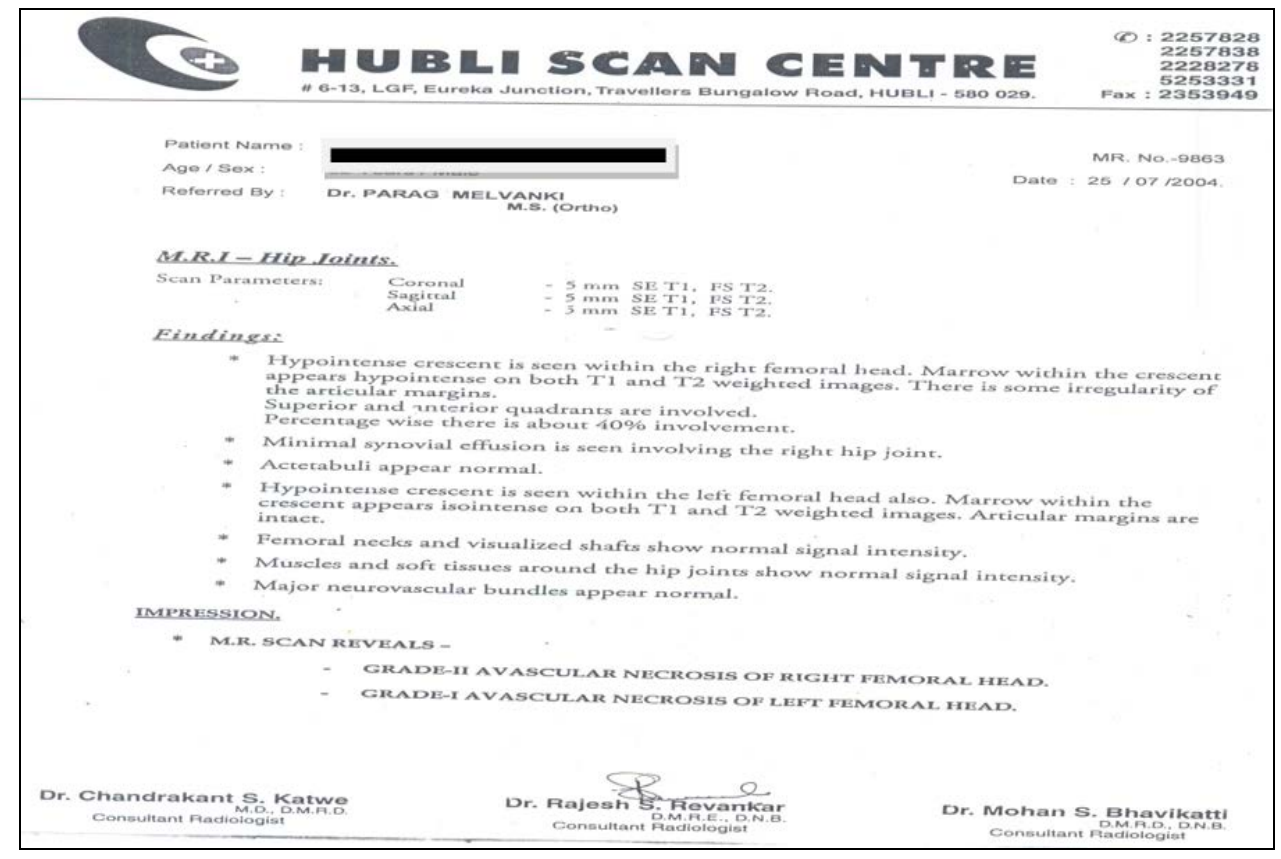




\section{MRI report after treatment}

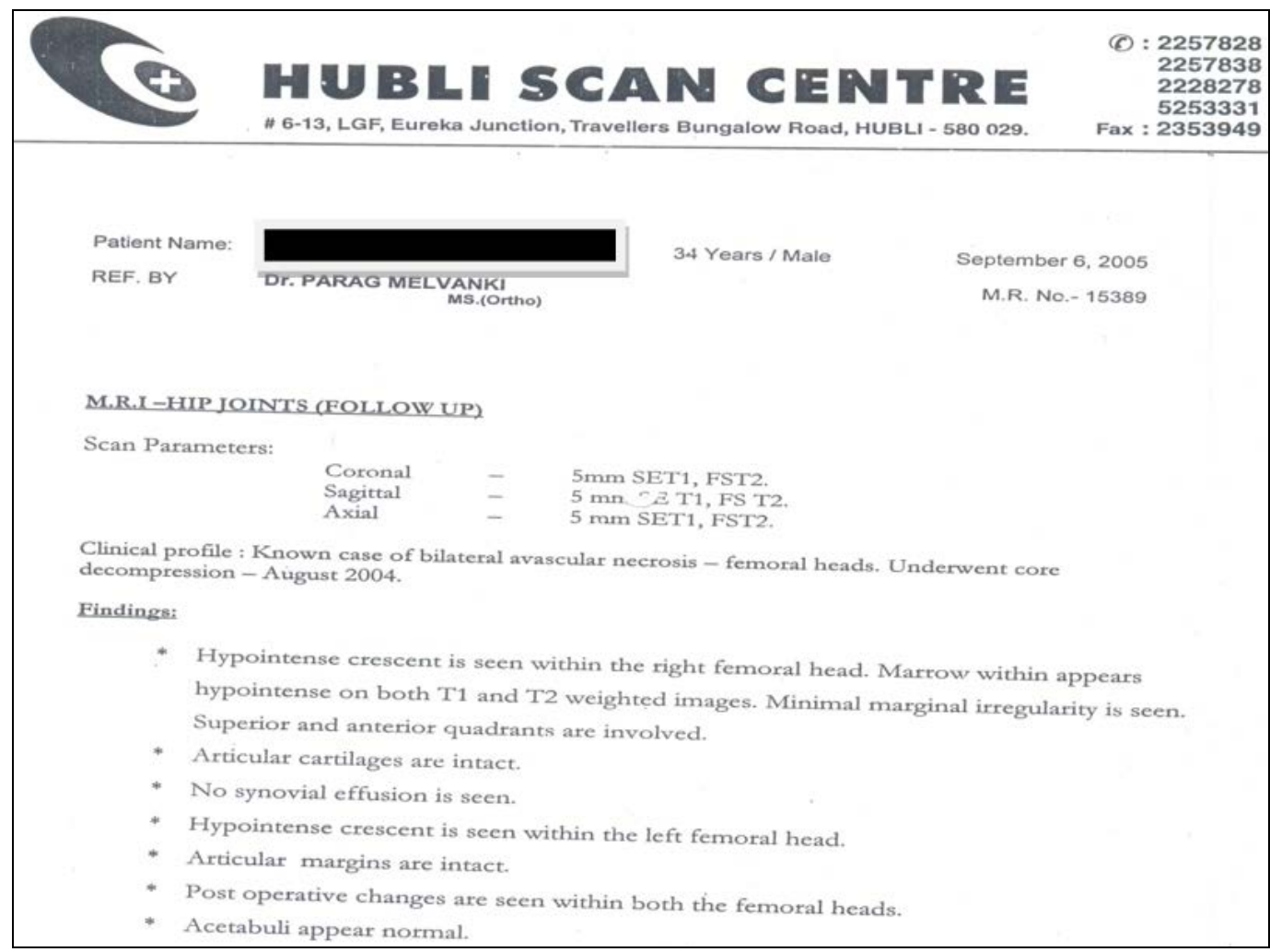

Case No. 2: Anxiety causing high Bored Depression (R. B. Cattell's abnormal trait - $\mathbf{D}_{7}$ ) predominates): Here was a case of lady patient Mrs. B, aged 30 years, suffering from Rheumatoid arthritis due to severe mental tension for her drunkard husband's torture. She was thin, sad, and in apathy. She had taken Nimusilid tablets for one year by allopathic doctor but without any remarkable effect. When she came to me on $23^{\text {rd }}$ March 2004 she had amenorrhoea since three months. She was mentally sad, apathetic, physically anaemic, soreness all over body, spindle shaped deformity of mid phallengeal joint of right hand's ring finger. She had soreness in back. All the joints of hands were affected along with knee joints and ankle joints. There was morning stiffness more than one hour and aggravated exertion, and cold and amelioration by rest and warmth. Patient was extremely chilly. She had piles previously. The above complaints started eight years back slowly when her husband started drinking wine and tortured her. She had no significant past history, only burning sole in her childhood. Her appetite was less, thirst was more. She had sweat more in palm and head during summer.

Lab. investigations: $\mathrm{Hb}$. $-9.6 \mathrm{gm} \%$, ESR $-58 \mathrm{~mm}$ at $1^{\text {st }}$ hour by westerngreen method, R.A. factor was positive, Uric acid was $6 \mathrm{mg} \%$, in D. L. C. - Neutrophills - 68\%, Lymphocytes - 30\%, Eosinophils - 2\%.

Conceptual Image: 1. Mental Generals: Sadness 2. Apathy 3.Causative modalities: Motion aggravation and Aggravation from cold 4.Pathological Generals: a) Uric acid diathesis b) Rheumatic diathesis c) Anaemia d) Haemorrhoids 5. Physical Generals: Amonaerrhoea

Repertorisation by $2^{\text {nd }}$ edition Murphy's Repertory as both generals and clinical symptoms are found.

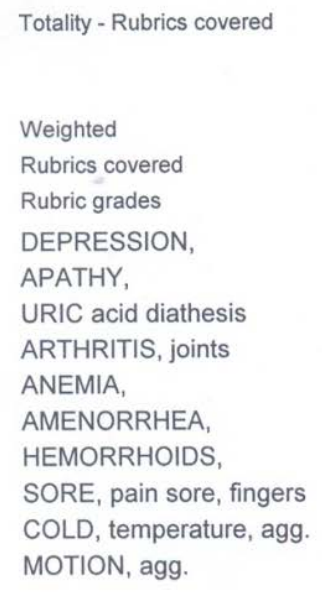

\begin{tabular}{|c|c|c|c|c|c|c|c|c|c|c|c|c|c|c|c|}
\hline & ळे & ฉ্ & $\frac{0}{\mathbb{J}}$ & 돓 & $\frac{E}{\frac{1}{d}}$ & $\frac{\substack{d \\
\frac{d}{2}}}{2}$ & \& & $\overline{\bar{S}}$ & $\begin{array}{l}\text { 윽 } \\
\text { के }\end{array}$ & 둔 & 这 & $\frac{2}{2}$ & $\overline{\bar{\Phi}}$ & 윪 & 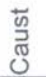 \\
\hline & 20 & 16 & 18 & 15 & 17 & 14 & 10 & 18 & 20 & 10 & 11 & 13 & 16 & 8 & 16 \\
\hline & 9 & 8 & 8 & 8 & 8 & 8 & 8 & 8 & 8 & 7 & 7 & 7 & 7 & 7 & 7 \\
\hline & 20 & 16 & 18 & 15 & 17 & 14 & 10 & 18 & 20 & 10 & 11 & 13 & 16 & 8 & 16 \\
\hline Murphy, Mind & 3 & 2 & 3 & 3 & 3 & 3 & 1 & 2 & 3 & 2 & 2 & 1 & 2 & 1 & 3 \\
\hline Murphy, Mind & & & 2 & 1 & & & 1 & 1 & & 1 & & & & 1 & \\
\hline Murphy, Diseas & $=1$ & & & & & 1 & & & & & & & & 1 & \\
\hline Murphy, Diseas & 2 & 3 & 2 & 1 & 2 & 2 & & 3 & 2 & & & 3 & 3 & & 2 \\
\hline Murphy, Diseas & 2 & 2 & 3 & 2 & 3 & 2 & 2 & 1 & 3 & 1 & 1 & 2 & 2 & 1 & 2 \\
\hline Murphy, Femali & 3 & 2 & 2 & 2 & 2 & 1 & 1 & 3 & 3 & 1 & 2 & 2 & 2 & 1 & 2 \\
\hline Murphy, Diseas & 3 & 1 & 2 & 3 & 2 & 2 & 1 & 2 & 3 & 1 & 2 & 2 & 2 & 1 & 3 \\
\hline Murphy, Hands & 1 & 1 & & & 1 & & 1 & & 1 & & 1 & 1 & & & \\
\hline Murphy, Enviro & 3 & 2 & 3 & 1 & 2 & 1 & 1 & 3 & 2 & 2 & 2 & & 2 & & 3 \\
\hline Murphy, Gener: & 2 & 3 & 1 & 2 & 2 & 2 & 2 & 3 & 3 & 2 & 1 & 2 & 3 & 2 & 1 \\
\hline
\end{tabular}


Post repertorial result analysis: Sepia and Sulphur are the two remedies coming neck to neck having value 20/9 and 20/8 respectively. Sulphur is hot patient so it is discarded as the patient is chilly.

So here we find great value in Sepia which has secured highest value also good medicine for high bored depression, which has caused rheumatoid arthritis, elevation (slight) of uric acid, anaemia and haemorroids by somatisation. Thus
Sepia 10M one dose was given followed by placebos. After one month she had regular menses and her finger's deformity and sore pain in all joints was reduced. Sepia $10 \mathrm{M}$ was repeated after 3 months. On $14^{\text {th }}$ September 2004 her Haemoglobin had increased to $11.2 \mathrm{gm} \%$, ESR was 52 $\mathrm{mm}$ at the end of $1^{\text {st }}$ hour, Serum uric acid $5.4 \mathrm{mg} \%$, and RA factor was weakly positive i.e. 1: 4 .Patient was now totally symptom free.

\section{Pathological reports before treatment}

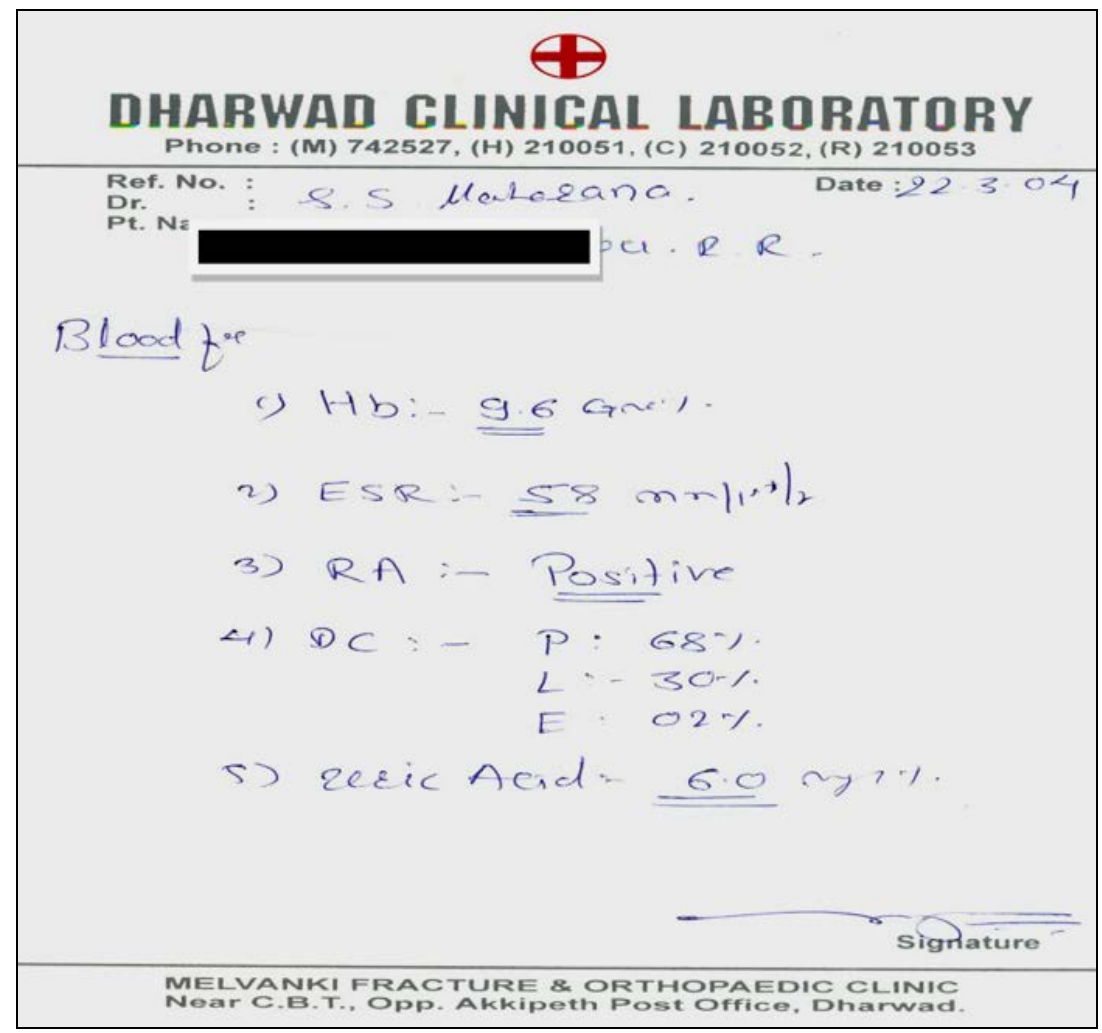

Pathological report after treatment

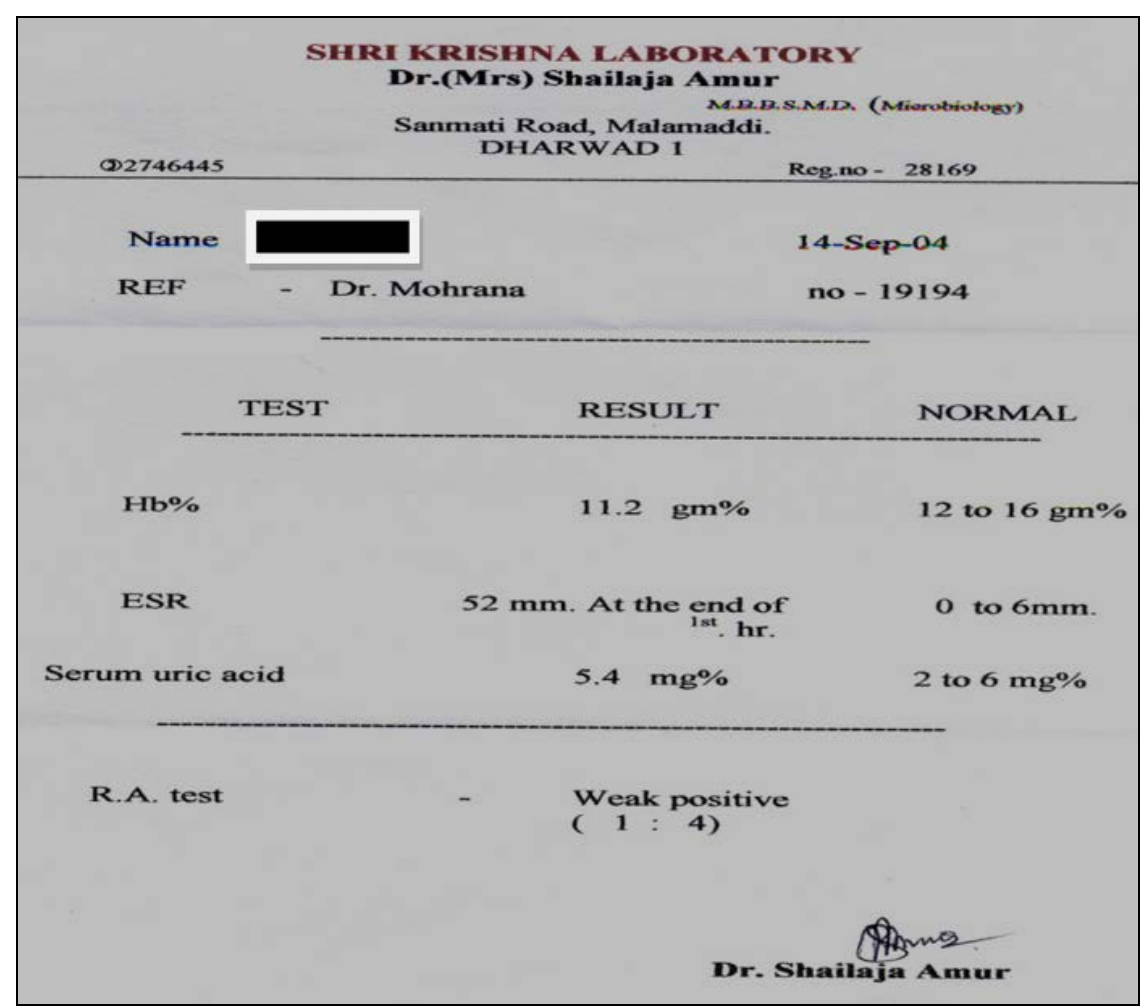


Case No. 3: Where suspicious trait (R.B. Cattell's normal trait factor $\mathbf{L}^{+}$) predominates.

Miss C, 58 years Hindu Female, complained on $27^{\text {th }}$ September 2009: Pain and swelling in all joints since 10 years. Taken allopathic medicines Swan neck deformity of all the fingers of the hands. All complaints are aggravated in cold and in night. Cannot sit in squating position comfortably. Pain in shoulder and small back. Desire open air.

Appetite less, Indigestion and flatulence, Desire salt, sweets and spicy, Aversion: Grams.

Thirst: 3 liters of water / day, Tongue: Coated and moist.
Stool: Not clear, 2 - 3 times / day.

Urine: Normal, Sweat: More in neck and arm pit. Palm sweating.

Mental Generals: She was highly suspicious of boys, did not married in fear of not to be taken care. Built: Thin and tall.

Menarchy: 14 years. Regular and normal flow. Menopause: 45 years.

She had taken all allopathic treatment without any remission of pain and deformity of hand occurred later.

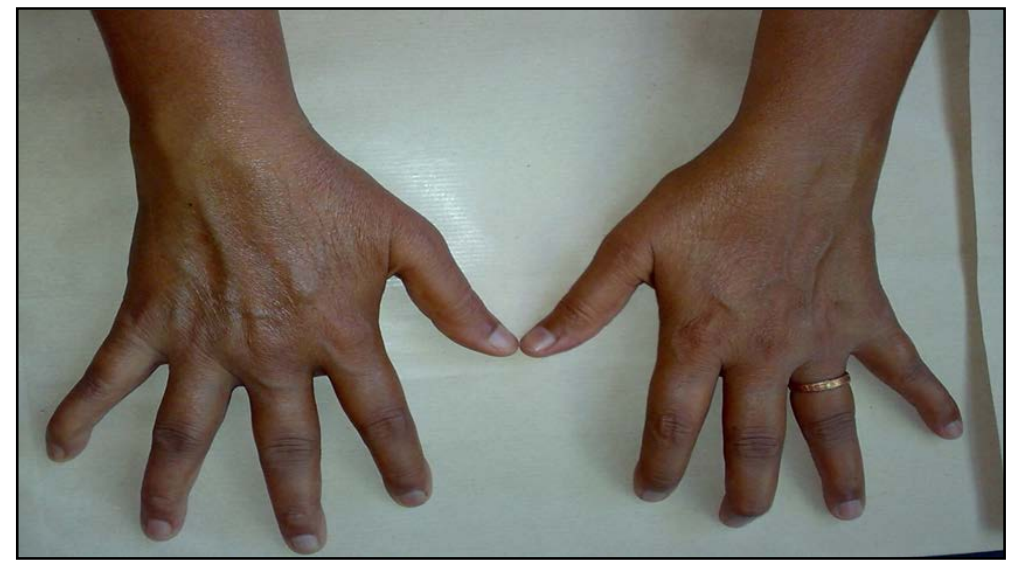

Diagnosis: RA factor was negative. Swan neck deformity, anaemia and high ESR are the criteria to diagnose as seronegative rheumatoid arthritis.

So by synthesis of the case, we find the conceptual imaget:
1. Suspicious 2. Fear of men 3.Night aggravation 4.Cold aggravation 5.Anaemia 6.Pain in joints 7. Open air amelioration 8. Flatulence after food 9. Delayed mense

\section{Repertorisation by Complete Repertory.}

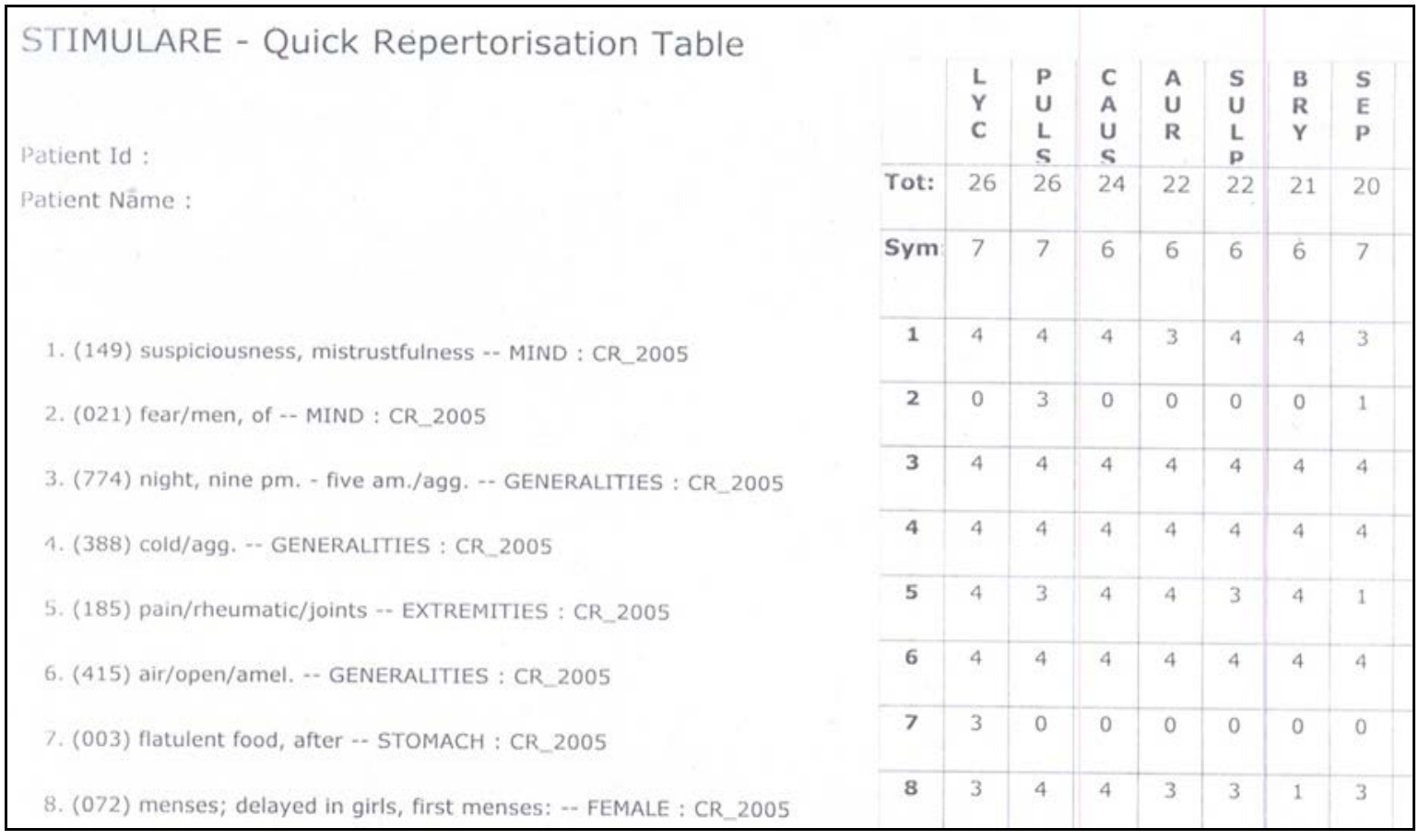

Post-reportorial Result Analysis: Lycopodium and Pulsatilla are the two remedies coming with highest value i.e. 26/7. Both are hot remedy. As Pulsatilla is not only highest value securing medicine, but also highest value medicine for the suspicious trait and fear complexity, no other medicines have such a high value, for both, Pulsatilla is differentiated as final choice medicine. Pulsatilla LM1 was given daily on $27^{\text {th }}$ September 2009 . 


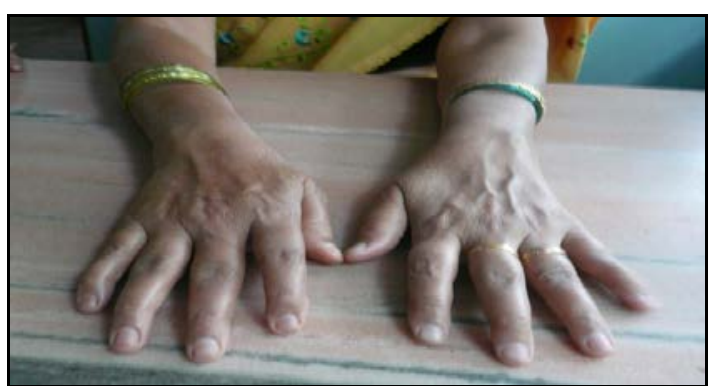

\section{Follow up}

1. On 3rd December 2008, there was no pain in fingers, swan neck deformity was reduced $90 \%$. Pain of shoulder and back reduced $80 \%$. This time Pulsatilla LM 2, once in a three days was repeated.

2. On $4^{\text {th }}$ February 2009, pain in finger joints, shoulder and back no more but cannot sit in squatting position for prolong period. On $4^{\text {th }}$ February 2009, the Haemoglobin increased from 9 gms\% to 10.2 gms\%, ESR reduced to $16 \mathrm{~mm}$ from $35 \mathrm{~mm}$ in the $1 \mathrm{st}$ hour by westerngreen method.

\section{Case No. 4: Where High intelligent Trait (R.B.Cattell's $\mathrm{B}+$ ) predominates.}

Mr. D. age 35 years, Hindu Male., Address - Dharwad. Present Complaints on 20th September 2004: 1. Low backache since 10 years, pain comes gradually and goes gradually, aggravated by exertion, standing, lying in bed, ameliorated by motion. 2. Pain in great toes of left leg since 6 months, sudden onset, severe pain and tenderness with swelling, aggravated by walking, and pressure, ameliorated by rest. 3. Indigestion since childhood, aggravated by fried foods. Desire sweet $^{+++}$. Thirst increased ${ }^{+++}$Mental: Most active and intelligent person, scored 95\% in Chemistry, did project on Ozone layer. Case had taken earlier modern treatment.

\section{Conceptual image by Synthesis of the case}

1. Peculiarity / Negative general: Hot patient but likes warm foods.

2. Pathological general: Uric acid diathesis.
3. Trait: Mentally keen (High intelligent trait).

4. Physical generals: Desires: Sweets ${ }^{++}$5.Thirst increased $^{+++}$. 6. Goes to stool soon after eating.

\section{Particulars}

a) Indigestion from childhood. < Fried foods, Indigestion

b) Low backache since 10 years.

$<$ Exertion, < Standing, < Lying on bed, > motion. Low backache, Pain comes gradually and goes gradually,

c) Pain, swelling and immobility in great toe of left leg since 6 months.

$<$ walking \& pressure. > by rest. Pain, swelling and immobility in great toe.

Provisional Diagnosis: Gout.

Miasmatic Diagnosis: Sycotic miasmatic state.

Repertory selected: Boger-Boenninghausen’s Repertory as with mental symptom and pathological general is also found.

\section{Reportorial Syndrome}

1. Uric acid diathesis, Agg. \& Amelio. in general, page1148

2. Active, busy, inclined to work, thoughts etc., Mind, page-191

3. Desire, sweets, Appetite, page-477

4. Thirst, Thirst, page 480

\section{Potential Differential Field (PDF)}

1. Hot patient but likes warm food.

2. Goes to stool soon after eating

3. Particulars:

a) Indigestion from childhood. < Fried foods, Indigestion

b) Low backache since 10 years.

$<$ Exertion, <Standing, <Lying on bed $>$ motion. Low backache: Pain comes gradually and goes gradually,

c) Pain, swelling and immobility in great toe of left leg since 6 months.

$<$ walking \& pressure. > by rest. Pain, swelling and immobility in great toe.

\section{Repertorisation by Boger's Repertory}

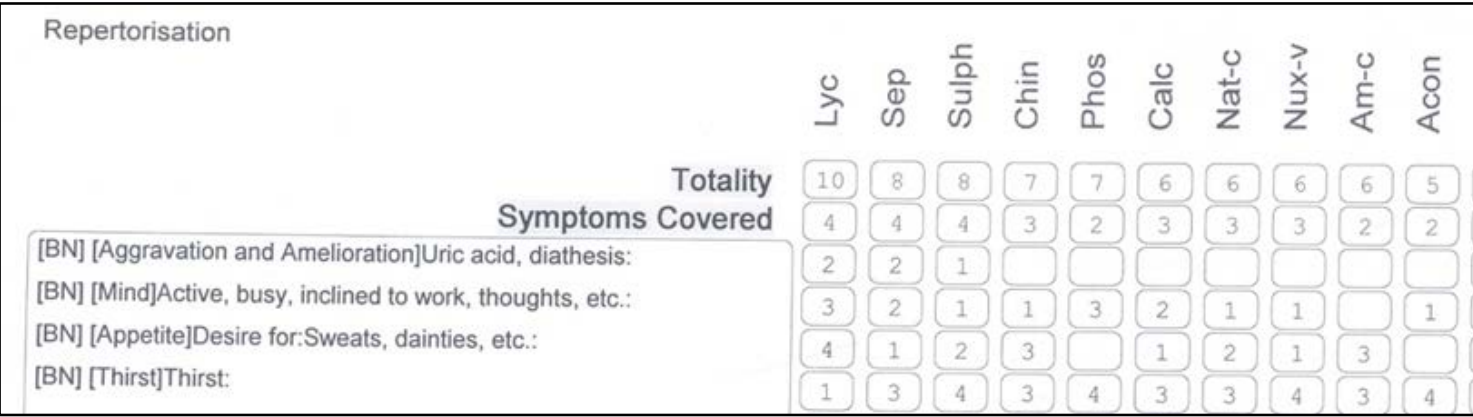

Post - reportorial analysis: By Materia Medica Knowledge we find that

Sepia is eliminated as patient is hot, and Sepia is a chilly remedy.

Lycopodium having the repertorial value 10/4 has the peculiarity / negative general of Hot patient likes warm foods, where as Sulphur having the repertorial value 8/4 has peculiarity /negative general hot patient but aversion to bathing. So as the patient is hot but likes warm food, the choice of remedy is Lycopodium and Lycopodium covers the particular symptoms by differentiation. So Lycopodium LM 1 O.D. was prescribed on $20^{\text {th }}$ September 2004.

\section{Follow up}

$6^{\text {th }}$ October 2004: Backache has decreased to 50\%. Pain and swelling in great toe as before. Indigestion is as before, 
Gastro-colic reflex is as before.

Medicine Prescribed: Lycopodium LM 1, daily.

11 $^{\text {th }}$ October 2004: Pain of back has decreased further $10 \%$ $<$ bending. Pain in left leg's great toe persists. No indigestion problem.

Medicine Prescribed: Lycopodium LM 1, daily.

$3^{\text {rd }}$ November 2004: Pain in back decreased $80 \%$. Pain in left toe was only on pressure. Swelling and tenderness has decreased $70 \%$.

Medicine Prescribed: Lycopodium LM 1, daily.

$8^{\text {th }}$ November 2004: Pain in back is decreased to $90 \%$, No pain at all in great toe of left leg. Swelling has decreased to $90 \%$. Uric acid level $-5.4 \mathrm{mg} / \mathrm{dl}$, ESR- $10 \mathrm{~mm} / 1^{\text {st }}$ hour as pain still little there.

\section{Pathological report before treatment}

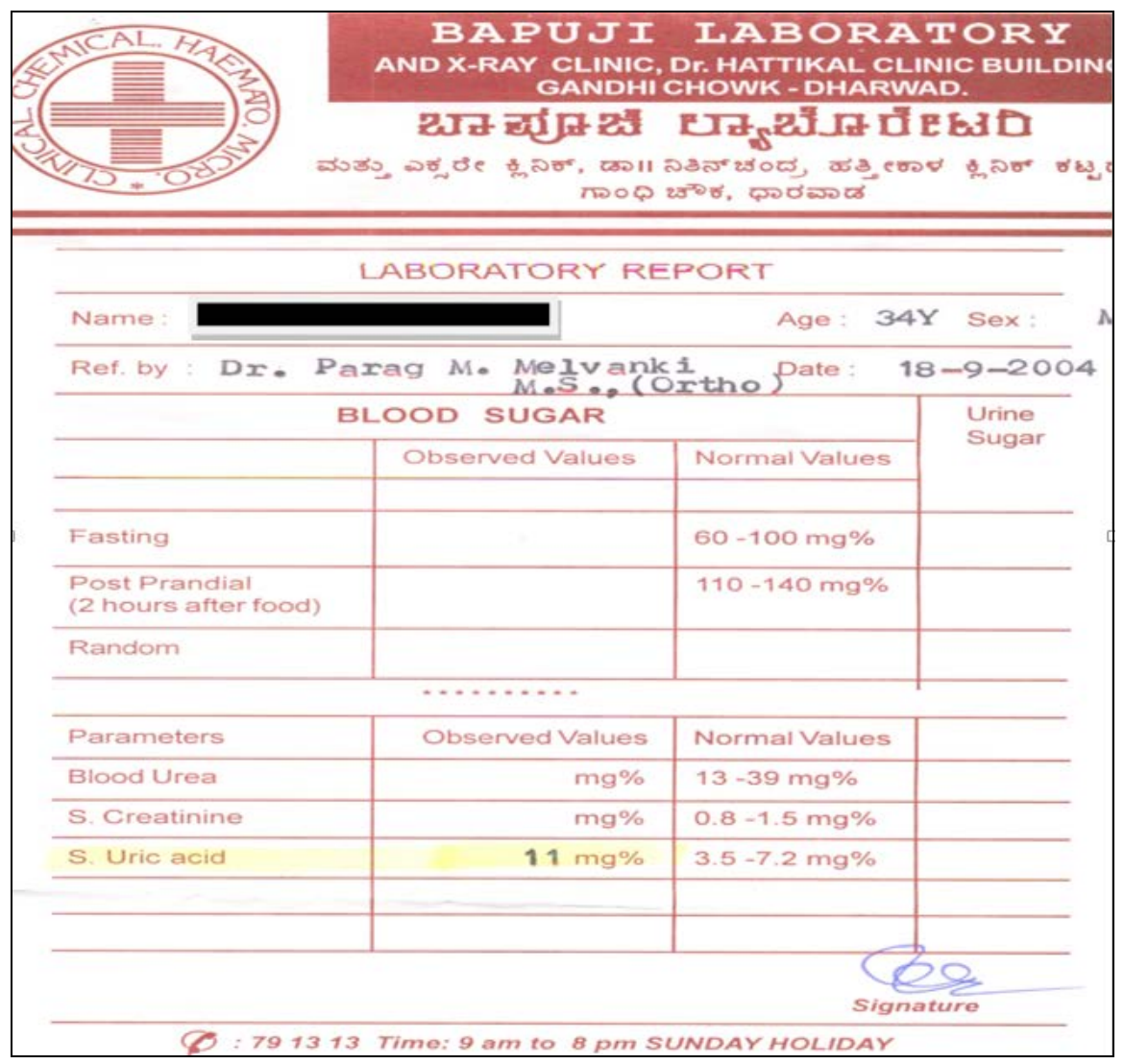

\section{Pathological report after treatment}

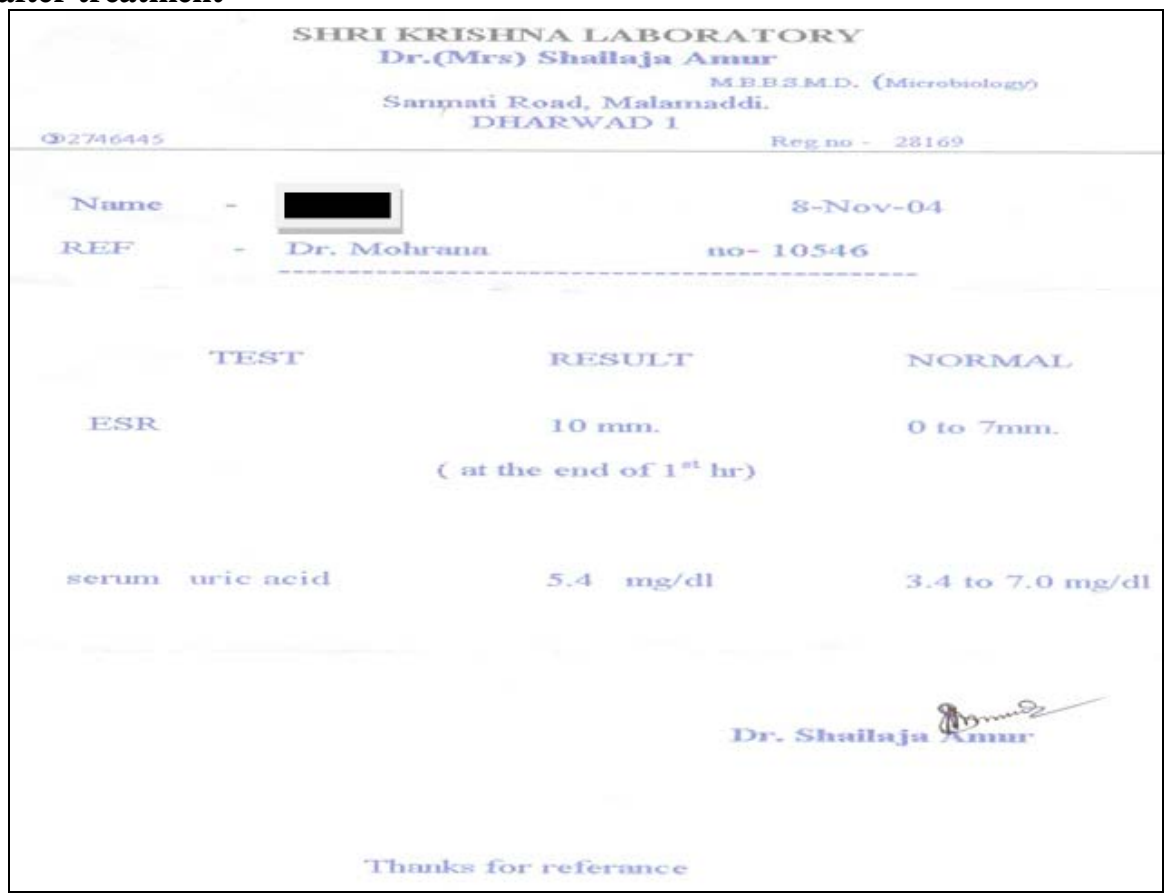


Case No. 5: Where R. B. Cattell's Tender - minded trait factor I+ prevails. Mr. E., 16 years old, Hindu Male, Occupation - Student,

Residence - Dharwad.

Present complaints on 26 $^{\text {th }}$ May 2004

Pain and swelling in all joints, shifting pain since 2 months, aggravated by movements.

History of present complaints: Patient was apparently well before 2 months. To start with he first developed fever with joint pain. He was under allopathic antibiotics. Fever subsided but joint pains and swelling remained. The details of the present complaints are:

Family history: Maternal uncle suffers from lumbar spondylosis and arthritis.

Personal history: Built - Thin and tall, Weight- $40 \mathrm{Kg}$., Height-5ft and 8 inches.

Appetite - Does not feel hungry at all.

Thirst - Little water at a time, tongue moist and clean.

Reaction to Heat and cold: Aggravated from cold

Likes open air. Baths in warm water

Mental generals: Simple, innocent, very mild.

General Physical Examination: No anaemia, No jundice, No cyanosis, No clubbing.

\section{Repertorisation by Kent's Repertory.}

Pulse rate - 83/minute, regular, low tension, no sclerotic changes on finger rolling to radial artery after stopping the blood flow by index and middle fingers. B.P.- 90/64 mmHg.

Systemic examination: C.V.S. - Apex beat at normal position. $\mathrm{S}_{1} \& \mathrm{~S}_{2}$ are normal, no $3^{\text {rd }}$ and $4^{\text {th }}$ heart sounds, no murmurs.

Respiratory System - Respiration rate - 20/minute, vesicular breathing, no added sounds.

Locomotor system - Wrist and ankle and knee joints are enormously swollen, extremely tender to touch and restricted movements of joints.

Investigations done on $29^{\text {th }}$ May 2004: Haemoglobin 6.9 gram $\%$, ESR $-80 \mathrm{~mm}$ at the $1^{\text {st }}$ hour. ASLO titre Positive (1:16), CRP - Positive (1:32).

Nosological Diagnosis - Post Streptococcal arthritis.

Miasmatic Diagnosis: Sycotic miasmatic state.

Conceptual Image by synthesis of the case: 1 . Aggravated from cold 2. Desire open air. 3.Thirst for small quantity often 4. Decreased appetite. 5. Anaemia 6.Swelling of joints 7. Shifting pain of joints P.D.F.: Mildness as not Qualified Mental but trait.

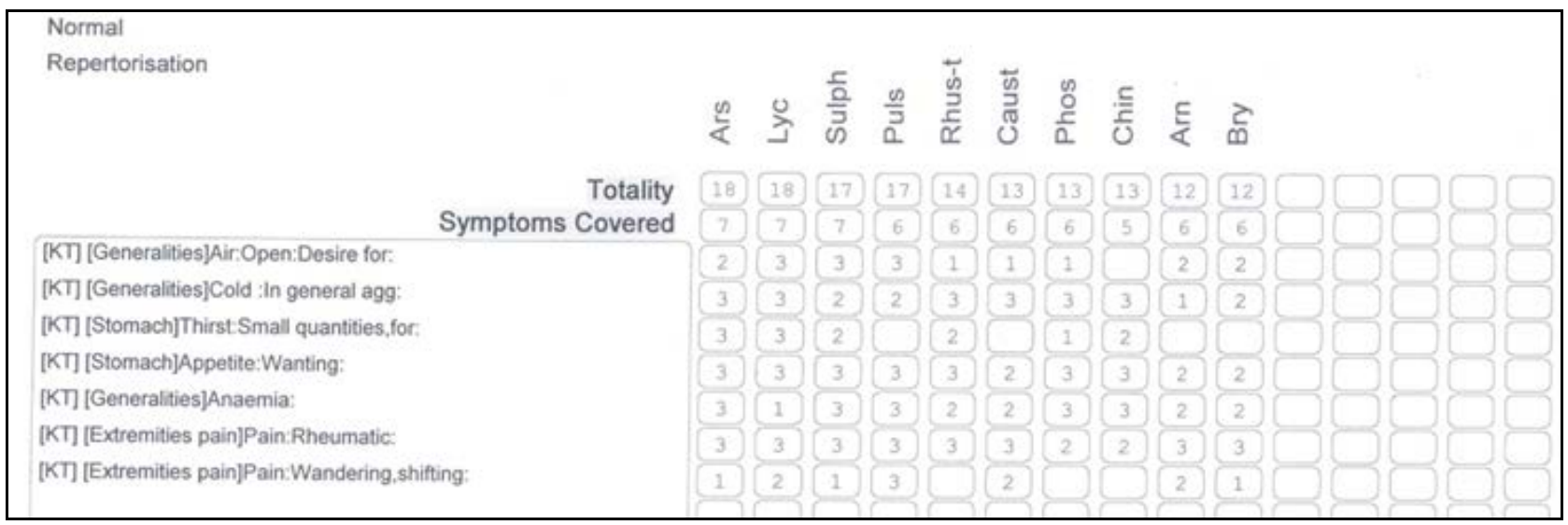

\section{PDF: Mildness}

Post - Repertorial Result Analysis: Pulsatilla comes as the highest valued remedy in both Kent and Boger's Repertory repertorisation. Pulsatilla is mild ${ }^{3}$ (Hering Guiding Symptoms: II MILD, GENTLE), anaemic, both pulsatilla and sulphur has high value in open air amelioration, characteristic wandering pain is most prominent in pulsatilla. Bryonia alba is not so mild as pulsatilla. So on $26^{\text {th }}$ May 2004, Pulsatilla 30, 4 globules every 6 hourly was prescribed in water doses.

\section{Pathological report before treatment}

Follow up: On 15 ${ }^{\text {th }}$ June 2004, patient had no pain at all. Swelling has reduced to $60 \%$. Pulse rate was $70 /$ minute, regular, normal tension. B.P. - 100/80 mmHg. Weight -41 K.G.

On $14^{\text {th }}$ July 2004, there was no swelling at all, no pain. ESR $-16 \mathrm{~mm} / 1^{\text {st }}$ hour, ASLO was weakly positive and CRP was negative. Pulse rate -74 /minute, regular, good tension. B. P. - 110/74 mmHg. Weight increased to 43 K.G. 


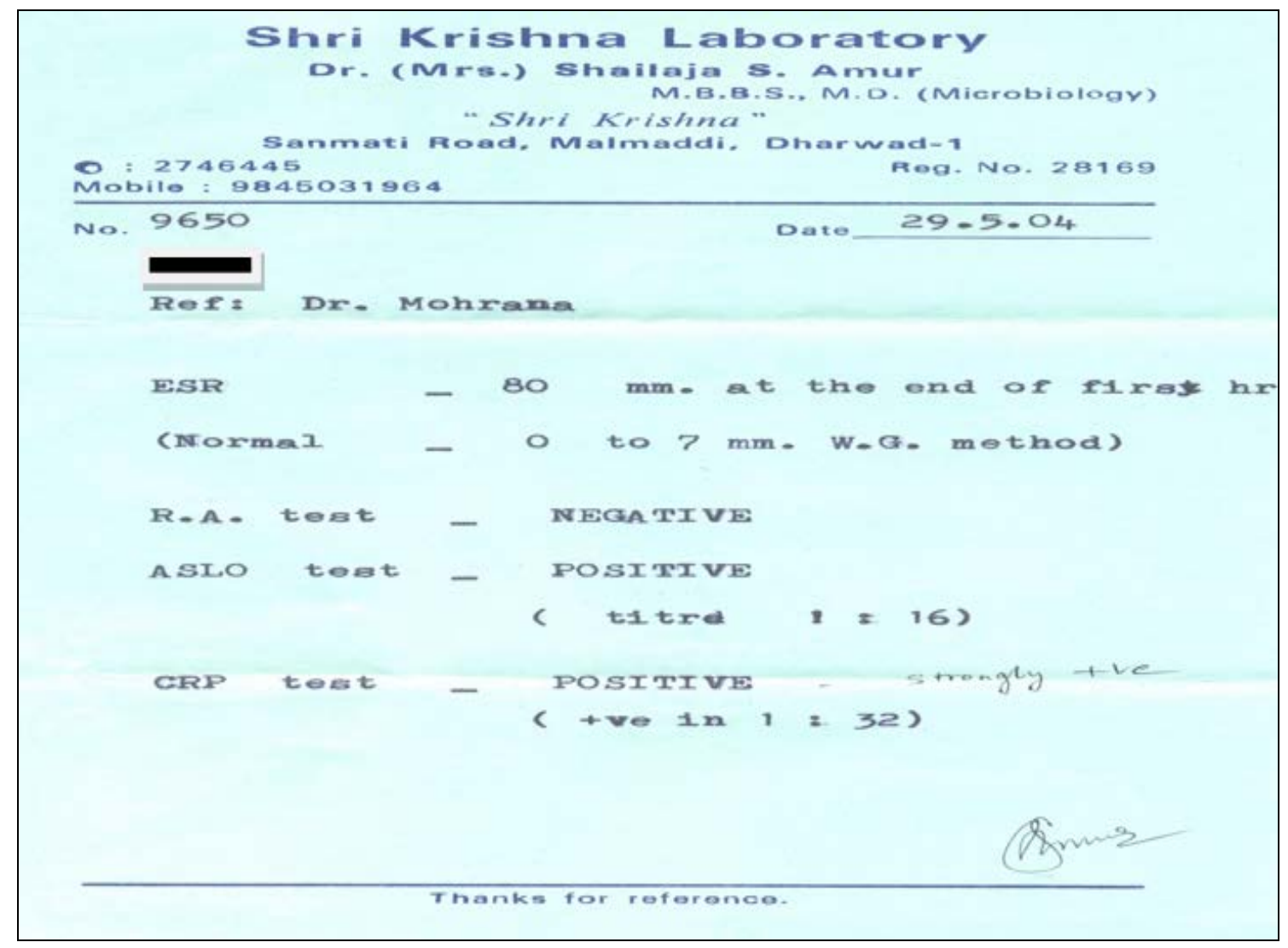

Pathological report after treatment:

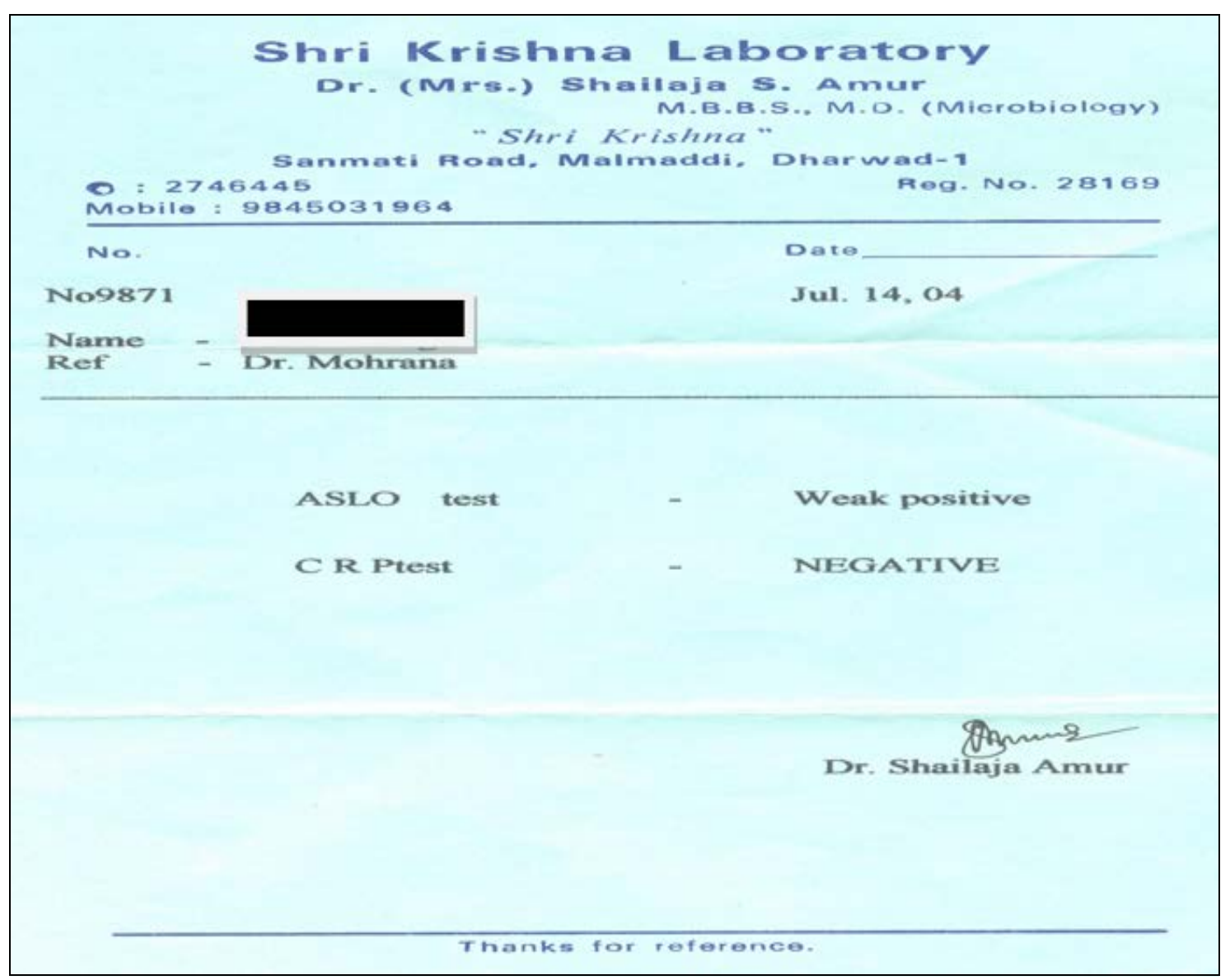

\section{Discussion}

The psychosocial causations, the befitting Raymond B. Cattell's normal and abnormal traits act as a differentiating factors for remedy selection. In $1^{\text {st }}$ case, anxiety ailment and pathological rubric together cured avascular necrosis of both hip joints problem by Asafoetida. Here Psora produced due 
to mental itch by virtue of intensity became syphilitic miasm. Asfoetida is the medicine of Psoro-syphilitic miasm, so was able to relieve the pain and patient was able to do daily work. In $2^{\text {nd }}$ case the anxiety ailment caused the high bored depression (Raymond B. Cattell's abnormal trait) causing apathy, and Rheumatoid arthritis and also little high of uric acid level and was cured when trait equivalent rubric depression and trait equivalent rubric apathy was considered which differentiated to remedy Sepia by sign and symptoms of rheumatoid arthritis and other problems also. Here mental itch procured from husband's torture developed psora, which in long run gave rise to sycotic miasmatic state and syphilitic miasmatic state. As a result see suffered sycotic miasmatic conditions rheumatoid arthritis, piles. Sepia was the trimiasmatic medicine, fitting best to high bored depression (Raymond B. Cattell's abnormal trait) with symptom of apathy (Idifference) was able to cure the case. In $3^{\text {rd }}$ case, the suspicious trait is the sycotic miasmatic state in mental level, produced seronagative reheumatoid arthritis and its equivalent rubrics was helpful for differentiation to remedy Pulsatilla. As a result, seronegative RA was cured. In the $4^{\text {th }}$ case, high intelligent trait equivalent rubric and pathological general rubric Uric acid diathesis was helpful for differentiation to the selection of remedy Lycopodium from repertorial result and the gout was cured. In $5^{\text {th }}$ case mildness trait was helpful for differentiation of remedy Pulsatilla at Post reportorial result analysis amongst other remedies which cured the case.

All those five cases were referred from ortho-pedician, or not cured by modern school of medicine and our special method of treatment on psychosocial causation and personality assessment relieved or cured.

\section{Conclusion}

The social causations are the internal itch for development of miasmatic state and traits (Raymond B. Cattell's normal and abnormal traits) can be utilized for repertorisation and/or differentiation keeping at PDF level at post reportorial result analysis. Thus these five critical case series train us that with synergy of traits and miasms / pathological generals we can achieve perfect drug selection for total cure through homoeopathic mental causations rubric and equivalent rubrics of traits, even in non-pathological finding case e.g., seronegative RA etc.

\section{References}

1. Sheehan B, Banerjee S. Review: Somatization in the elderly. International journal of geriatric psychiatry 1999;14(12):1044-1049. https://doi.org/10.1002/(sici)10991166(199912)14:12<1044::aid-gps55>3.0.c0;2-0

2. Kent JT. Lectures on Homoeopathic Philosophy. B. Jain Publishers (P) Ltd. Reprint Edition 1997, 134.

3. Hahnemann S. The Chronic Diseases (Theoretical Part. B. Jain Publishers (P) Ltd., New Delhi. Reprint Edition 1996, 31-33.

4. Swedenborg E. Divine Providence. Swedenborg Foundation 320 North Church Street West Chester, PA 19380 USA. Pp. 2

5. Internet Source. Swedenborgphilosophy.org/swedenbrg-philosophy/ the new philosophy by Rev. Hugo Lj Odhner

6. Internet source: Swedenborg philosophy.org/swedenbrg - philosophy/ the new philosophy by Rev. Hugo Lj Odhner

7. Internet source: Swedenborg philosophy.org/swedenbrg - philosophy/Enneeds of Spiritual and Physical sub-degrees by Ian Thompson

8. Kent JT. Lectures on Homoeopathic Philosophy. B. Jain Publishers (P) Ltd. Reprint Edition 1997, 134.

9. Kent JT. Lectures on Homoeopathic Philosophy. B. Jain Publishers (P) Ltd. Reprint Edition 1997, 134.

10. Kent JT. Lectures on Homoeopathic Philosophy. B. Jain Publishers (P) Ltd. Reprint Edition 1997, 24.

11. Kent JT. Lectures on Homoeopathic Philosophy. B. Jain Publishers (P) Ltd. Reprint Edition 1997, 24.

12. Trofimova I, Robbins TW, Sulis WH, Uher J. Taxonomies of psychological individual differences: biological perspectives on millennia-long challenges. Philosophical transactions of the Royal Society of London. Series B, Biological sciences 2018;373(1744):20170152.

https://doi.org/10.1098/rstb.2017.0152

13. Allport GW. Personality: A psychological interpretation. New York: H. Holt and. Company.

14. Herbert AR. Analysis of case. The Principles and Art of Cure by Homoeopathy, Third edition. B. Jain Publishers (P) Ltd. New Delhi 2017, 74.

15. Gulliford JP. Personality by J. P. Gulliford. New York: Mac Graw - Hill Book Company 1959, 13-562

16. Chauhan SS. Advanced Educational Psychology; Fifth Edition, New Delhi: Vikas Publishing House Pvt. Ltd 1989, 319, 324.

17. Ryckman RM. Theories of Personality, $5^{\text {th }}$ edition, Califernia: Brooks/Cole Publishing Company 1993, 261.

18. Ryckman RM. Theories of Personality, $5^{\text {th }}$ edition, Califernia: Brooks/Cole Publishing Company 1993, 263,

19. Ryckman RM. Theories of Personality, $5^{\text {th }}$ edition, Califernia: Brooks/Cole Publishing Company 1993, 270.

20. Ryckman RM. Theories of Personality, $5^{\text {th }}$ edition, Califernia: Brooks/Cole Publishing Company. Reddy SR. Effect of homoeopathic medicine Lycopodium clavatum in urinary calculi. International Journal of Applied Research. 2017;3(1):790-1. 271.

21. Internet source: verywellmind.com/cattells-16personality-factor-2795977. Cattell's 16 Personality Factors By Kendra Cherry Reviewed by Amy Morin, LCSW on November 262019

22. Murphy R. Mind chapter. Third Revised Edition (2010).B.Jain Publishers (P) Ltd. Noida 2019.

23. Shroyen F. Essential Synthesis. B. Jain Publishers (P) Ltd. New Delhi 2012.

24. Kent JTZ. Repertory of the Homoeopathic Materia Medica, Low Priced Edition. B. Jain Publishers (P) Ltd. Noida 2019.

25. Boger CM. Boger - Boenninghausen's Charecteristics and Repertory, $49^{\text {th }}$ Impression, B. Jain Publishers (P) Ltd. Noida 2019. 